\title{
Distribution and Neurochemistry of the Porcine Ileocaecal Valve Projecting Sensory Neurons in the Dorsal Root Ganglia and the Influence of Lipopolysaccharide from Different Serotypes of Salmonella spp. on the Chemical Coding of DRG Neurons in the Cell Cultures
}

\author{
Anita Mikołajczyk ${ }^{1, *(1)}$, Anna Kozłowska ${ }^{2}$ and Sławomir Gonkowski ${ }^{3}$ \\ 1 Department of Public Health, Faculty of Health Sciences, Collegium Medicum, University of Warmia and \\ Mazury in Olsztyn, Warszawska 30 Str., 10-082 Olsztyn, Poland \\ 2 Department of Human Physiology, School of Medicine, Collegium Medicum, University of Warmia and \\ Mazury in Olsztyn, Warszawska 30 Str., 10-082 Olsztyn, Poland; kozlowska.anna@uwm.edu.pl \\ 3 Department of Clinical Physiology, Faculty of Veterinary Medicine, University of Warmia and Mazury in \\ Olsztyn, Oczapowskiego 13 Str., 10-718 Olsztyn, Poland; slawekg@uwm.edu.pl \\ * Correspondence: anita.mikolajczyk@uwm.edu.pl
}

Received: 3 August 2018; Accepted: 25 August 2018; Published: 28 August 2018

\begin{abstract}
The ileocecal valve (ICV) — a sphincter muscle between small and large intestine-plays important roles in the physiology of the gastrointestinal (GI) tract, but many aspects connected with the innervation of the ICV remain unknown. Thus, the aim of this study was to investigate the localization and neurochemical characterization of neurons located in the dorsal root ganglia and supplying the ICV of the domestic pig. The results have shown that such neurons mainly located in the dorsal root ganglia (DRG) of thoracic and lumbar neuromers show the presence of substance $P$ (SP), calcitonin gene-related peptide (CGRP), and galanin (GAL). The second part of the experiment consisted of a study on the influence of a low dose of lipopolysaccharide (LPS) from Salmonella serotypes Enteritidis Minnesota and Typhimurium on DRG neurons. It has been shown that the LPS of these serotypes in studied doses does not change the number of DRG neurons in the cell cultures, but influences the immunoreactivity to SP and GAL. The observed changes in neurochemical characterization depend on the bacterial serotype. The results show that DRG neurons take part in the innervation of the ICV and may change their neurochemical characterization under the impact of LPS, which is probably connected with direct actions of this substance on the nervous tissue and/or its pro-inflammatory activity.
\end{abstract}

Keywords: ileocecal valve (ICV); LPS from S. Enteritidis; LPS from S. Minnesota; LPS from $S$. Typhimurium; neuropeptides of DRG

\section{Introduction}

The innervation of the gastrointestinal (GI) tract consists of two parts: the intestinal nervous system (ENS) and extrinsic innervation [1-4]. The ENS, located in the wall of the oesophagus, stomach, and intestine, is built of millions of neuronal cells divided into ganglionated plexuses, whose quantity depends on animal species [5]. Enteric neurons are very diverse in their morphology, physiology, and neurochemical characteristics and regulate the majority of the functions of the GI tract $[1,5]$. Due to the significant degree of the independence from the brain, the ENS is called the "second" 
or "intestinal" brain [6]. However, despite a high degree of autonomy, the ENS is, to some extent, controlled by the central nervous system by the extrinsic innervation of the GI tract. This innervation consists of three fundamental parts, including parasympathetic efferent innervation, sympathetic efferent innervation and afferent innervation $[7,8]$. The precise localization of neurons participating in the extrinsic innervation of the stomach and intestine clearly depends on innervated segment of the GI tract. In the case of the parasympathetic nervous system, the major part of the GI tract (from oesophagus to transverse colon) is innervated by fibres which are branches of the vagal nerve [7]. Only caudal fragments of the GI tract (descending colon, rectum and anus) are supplied by nerves originating from the parasympathetic nuclei within the intermediolateral column of the sacral spinal cord [9]. In turn, sympathetic neurons innervating the GI tract may be located in the sympathetic chain ganglia and prevertebral ganglia, including the celiac, superior and inferior mesenteric, or pelvic ganglia $[2,3,7]$. Apart from sympathetic and parasympathetic extrinsic innervation, the GI tract is also supplied by afferent nerves which conduct sensory and pain stimuli from the stomach and intestine to the central nervous system. These nerves are the processes of neuronal cells situated in the nodose ganglia of the vagal nerve or dorsal root ganglia [8]. Previous studies have shown that sensory neurons supplying the gut may contain a wide range of neuronal active substances $[8,10]$. Among them, the most important factors in sensory and pain stimuli conduction seem to be substance P (SP) and calcitonin gene-related peptide (CGRP). Moreover, it is known that sensory neuronal cells innervating the GI tract may undergo neurochemical changes during pathological processes taking part in the stomach and intestine [8-10], but knowledge concerning these aspects is extremely limited.

The ileocecal valve (ICV), a sphincter muscle between small and large intestine, prevents the reflux of colonic content to the ileum and serves as a barrier to the entering of colonic microbial flora to the small intestine [11-13]. It should be underlined that previous studies on the innervation of the ICV are few [12] and the sensory neurons innervating this part of the GI tract have not been studied at all. On the other hand, it is known that the organization of the ICV innervation is specific $[12,14]$ and disturbances within it may play important roles in disorders of this part of the GI tract, including constipation, feeling bloated, and/or diarrhoea [12,15]. The knowledge of why the ICV can become impaired, which can lead to many pathological processes such as small intestine bacterial overgrowth (SIBO), is still unclear. This assumes that it is rather the composition of the bacterial species that is more crucial than the number of bacteria. Maybe interaction of some bacteria or some bacterial toxins with the nervous system can also play a role in ICV dysfunction. Due to the above, the study of the interaction between sensory neurons supplying ICV and lipopolysaccharide (LPS) from Salmonella spp. seems very interesting.

It should be pointed out that the ileum and cecum were the main sites of Salmonella growth in a latent carrier mouse. Thus, parts of the intestine can be strategic places for Salmonella proliferation in animals without showing any clinical symptoms of disease during latent infection [16]. Additionally, LPS can be derived from the dead Salmonella existing in this part of the intestine. It is known that LPS is present within the cellular membrane of all Gram-negative bacteria and demonstrates negative activity on living organisms [17]. Namely, this substance damages various internal organs, which is connected with the release of free radicals. Moreover, LPS acts on the immunological system, causing fever and septic shock [18]. Previous studies have also shown that LPS may affect the nervous system and is involved in, or connected with, neurodegenerative diseases. However, apart from the fact that LPS may change the expression of the neuronal factor in the internal organs [19-21], knowledge concerning changes in neurochemical characterization of neuronal cells under the influence of this substance is lacking. Moreover, it is known that LPS is not a homogeneous substance [22-26]. Additionally, LPS from different species are characterized by various activities $[23,27,28]$ but, until now, the studies on differences in LPS activity derived from various serotypes connected with the influence of this substance on neuronal neurochemical characterization have not yet been studied.

It should be also underlined that the selection of the domestic pig as an experimental animal during this investigation was not accidental. It is relatively well known that the domestic pig is very 
good animal model of processes occurring in the human organism, due to well confirmed biochemical, neurochemical, and physiological similarities between these species [29]. Thus, the results obtained during this study may reflect the mechanisms connected with the influence of LPS on the human nervous system. The aim of these studies was to investigate the distribution and neurochemistry of the DRG sensory neurons supplying the ICV under physiological conditions Moreover, the influence of a low dose of LPS from various serotypes of Salmonella on the neurochemical characterization of neurons located in DRG during the cell cultures has been also studied.

\section{Results}

During the present study, neuronal cells supplying the ICV were observed in bilateral DRG from neuromers Th7 to L4, and the differences between right and left DRG were not very clear (Figure 1).

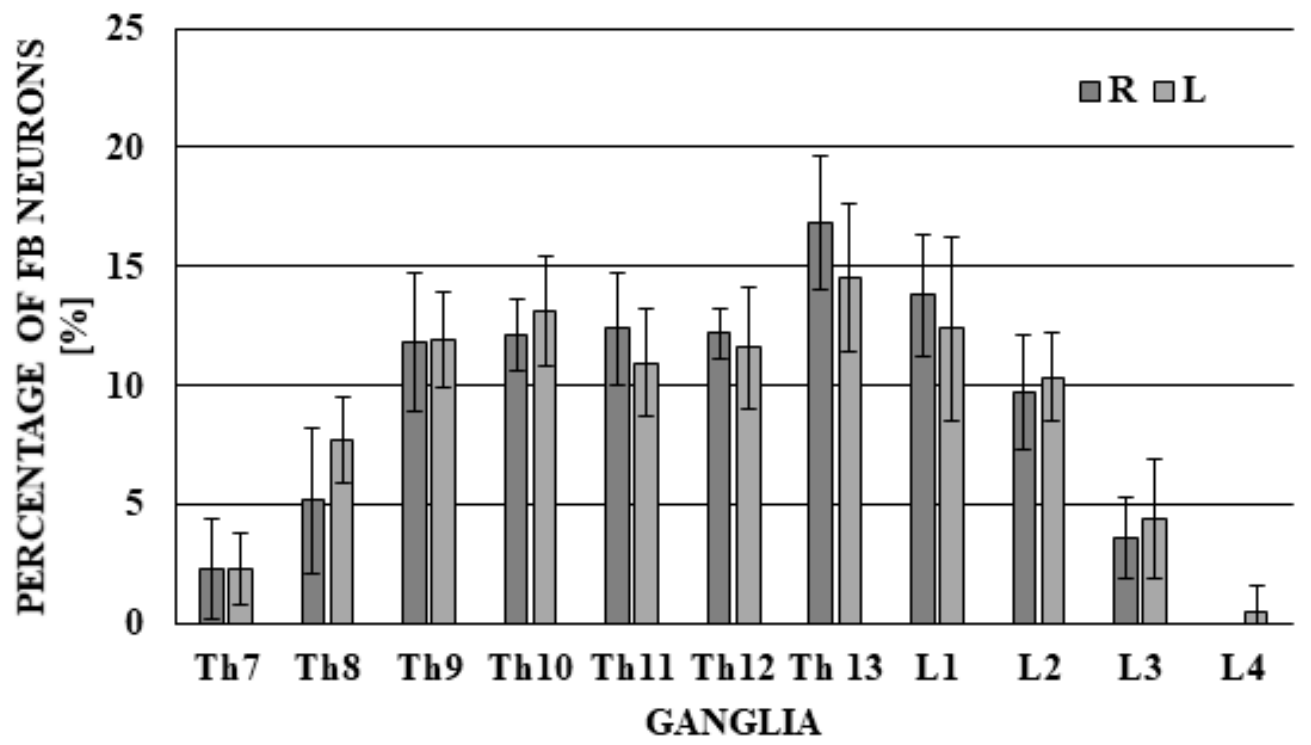

Figure 1. The distribution of fast blue (FB)-labelled neurons supplying the porcine ileocecal valve located in dorsal root ganglia (DRG). The total number of FB-positive neurons located in left and right DRG was considered as $100 \%$ (separately for left and right DRG).

The largest number of FB-positive cells was located in neuromers Th13 $(16.88 \pm 2.81 \%$ of all $\mathrm{FB}+$ neurons) in the right DRG and $14.54 \pm 3.07 \%$ in the left DRG). A slightly lower number of neuronal cells supplying the ICV was noted in neuromers Th9-Th12 (from $11.82 \pm 2.90 \%$ to $12.41 \pm 2.36 \%$ in right DRG and from $10.95 \pm 2.26 \%$ to $13.16 \pm 2.32 \%$ in left DRG) and L1-L2, respectively, $13.81 \pm 2.58 \%$ and $9.70 \pm 2.41 \%$ in right DRG, and $12.42 \pm 3.85 \%$ and $10.37 \pm 1.87 \%$ in left DRG). Significantly fewer neurons were present in neuromers Th7-Th8 $(2.29 \pm 2.10 \%$ and $5.18 \pm 3.10 \%$ in right DRG and $2.34 \pm 1.51 \%$ and $7.76 \pm 1.81 \%$ in left DRG) and L3 $(3.62 \pm 1.71 \%$ in right DRG and $4.45 \pm 2.51 \%$ in left $\mathrm{DRG}$ ), and within the neuromer L4, FB+ neuronal cells were observed only sporadically (FB+ neurons were observed only in left DRG in quantities of $0.51 \pm 1.15 \%$ ). The total average number of FB+ neurons investigated in one animal amounted to $219.00 \pm 67.30(108.40 \pm 35.98$ in right DRG and $110.60 \pm 32.24$ in left DRG)

The highest number of sensory neurons supplying the ICV showed immunoreactivity to CGRP. The percentage of CGRP-positive cells amounted to $57.33 \pm 6.89 \%$ of all FB+ cells (Figure 2A). The presence of SP was observed in a slightly lower percentage of the ICV projecting neurons (Figure 2B). This value reached $50.10 \pm 8.71 \%$. In turn, neurons immunoreactive to GAL were the least numerous. GAL was noted in $39.52 \pm 5.33 \%$ of all FB-positive cells (Figure $3 \mathrm{C}$ ). 

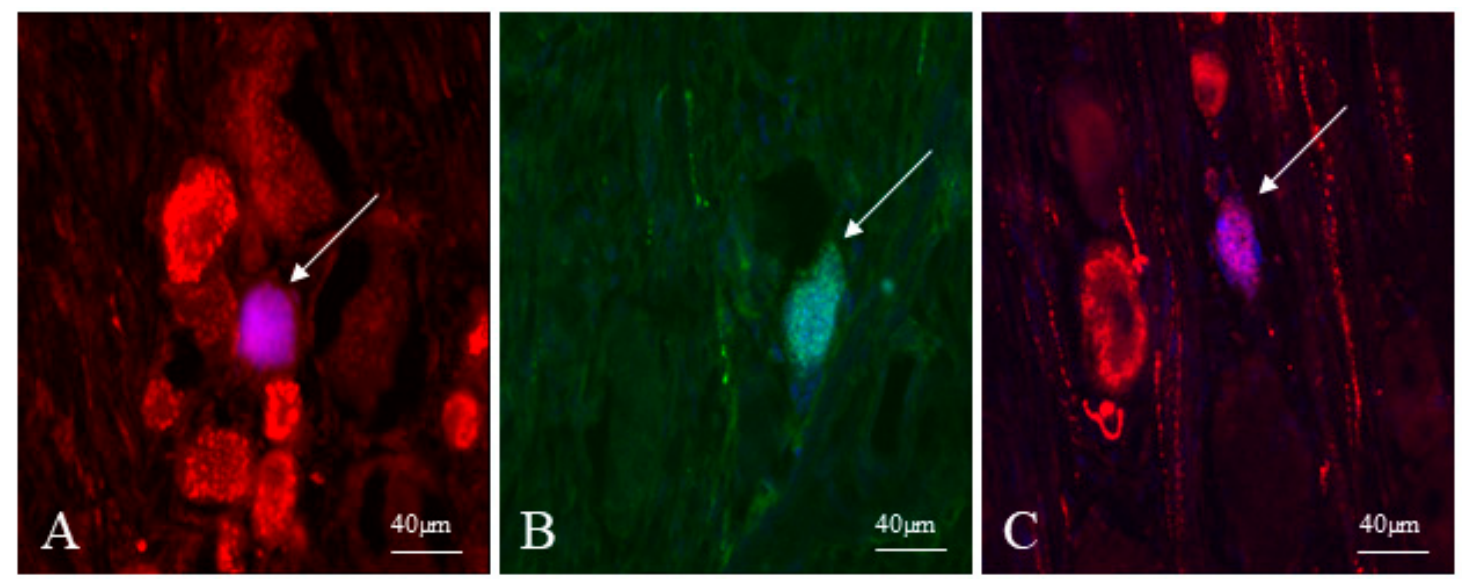

Figure 2. Fast blue-positive neurons in the dorsal root ganglia (DRG) supplying the ileocecal valve (ICV) (indicated with arrows) immunoreactive to calcitonin gene related peptide (CGRP) (A), substance $\mathrm{P}(\mathrm{SP})$ (B) and galanin (GAL) (C).

Regarding in vitro culture, it should be underlined that we tried to count both all FB-labelled neurons projecting to the ICV and unlabelled neurons projecting to other parts of the intestine and other organs. Unfortunately, the number of FB-labelled neurons was too low to get reliable statistically results and, therefore, the results obtained from all the population of labelled and un-labelled neurons are presented in the present study.

Studies conducted on cell cultures have shown that LPS derived from all bacterial serotypes studied did not change the average number of neurons on a glass coverslip. The number of neurons in the control group amounted to $48.07 \pm 7.62$, whereas under the influence of LPS, they achieved $48.69 \pm 7.85,48.66 \pm 8.92$, and $48.10 \pm 8.73$ under the impact of LPS S. Enteritidis, LPS S. Minnesota and LPS S. Typhimurium, respectively.

Moreover, during the present study, the influence of LPS on neurons immunoreactive to SP and/or GAL was observed and changes clearly depended on bacterial serotype. In control animals, SP-positive cells amounted to $60.90 \pm 3.34 \%$ of all neurons. LPS S. Enteritidis caused the increase of the number of SP + neurons to $82.09 \pm 4.43 \%$, whereas LPS S. Minnesota and LPS S. Typhimurium resulted in a decrease in the percentage of such cells (to $41.48 \pm 3.67 \%$ and $30.83 \pm 3.71 \%$, respectively) (Figure 3).

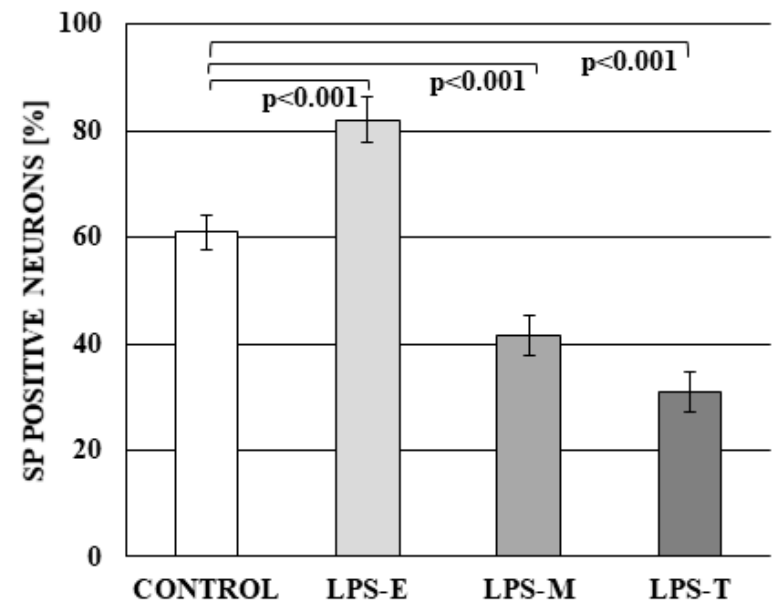

Figure 3. The percentage of neurons in dorsal root ganglia (DRG) immunoreactive to substance P (SP) in the control group and under the impact of LPS from S. Enteritidis (LPS-E), S. Minnesota (LPS-M), and $S$. Typhimurium (LPS-T). Statistically different at $p<0.001$ as compared to the control group. 
A different situation was observed in the case of GAL-positive neurons. In control animals, the percentage of such cells amounted to $55.44 \pm 4.16 \%$. LPS S. Enteritidis and LPS S. Minnesota caused the decrease in the number of GAL + neurons (to $27.51 \pm 1.40 \%$ and $26.82 \pm 7.08 \%$, respectively), whereas under the impact of LPS S. Typhimurium, this value achieved $52.81 \pm 6.80 \%$ and was not significantly statistically different from the percentage observed in the control group (Figure 4).

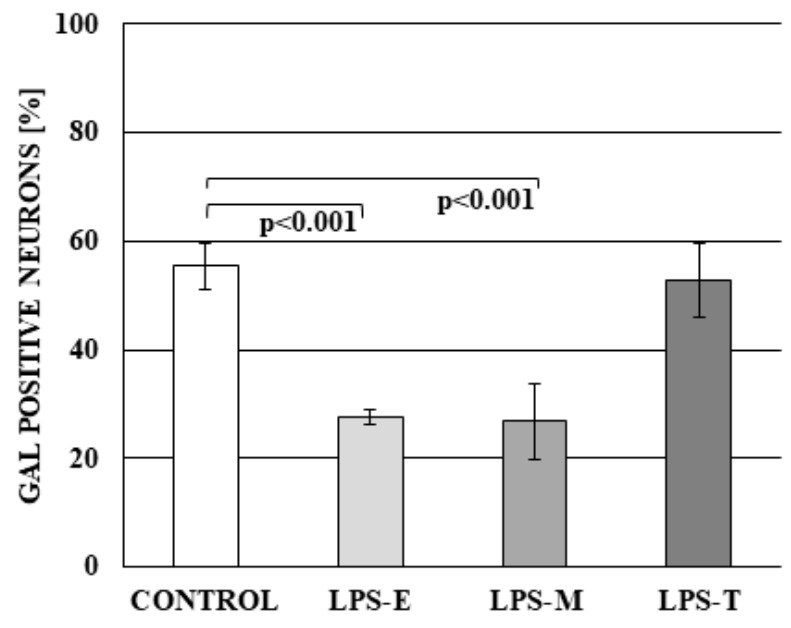

Figure 4. The percentage of neurons in dorsal root ganglia (DRG) immunoreactive to galanin (GAL) in control group and under the impact of LPS from S. Enteritidis (LPS-E), S. Minnesota (LPS-M), and $S$. Typhimurium (LPS-T). Statistically different at $p<0.001$ as compared to the control group.

During the present investigation, the influence of LPS derived from all bacterial serotypes studied on the percentage of CGRP-positive neurons was not observed. The percentage of such neurons amounted to $67.19 \pm 3.49 \%$ in control group, $67.52 \pm 3.96 \%$ in LPS S. Enteritidis group, $69.08 \pm 4.51 \%$ in LPS S. Minnesota group and $67.53 \pm 5.35 \%$ in the LPS S. Typhimurium group. Differences between the mentioned above values were not statistically significant (Figure 5).

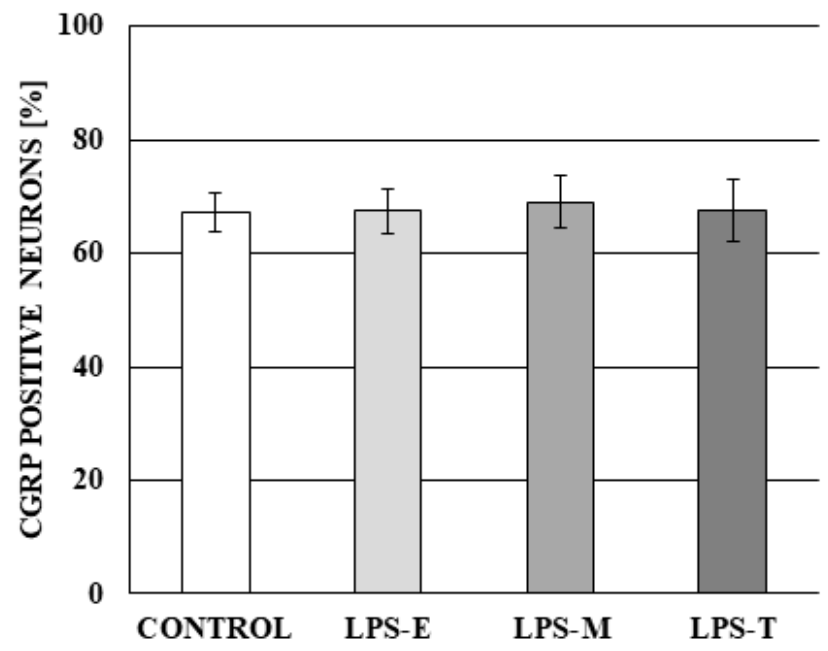

Figure 5. The percentage of neurons in dorsal root ganglia immunoreactive to calcitonin gene-related peptide (CGRP) in control group and under the impact of LPS from $S$. Enteritidis (LPS-E), S. Minnesota (LPS-M), and S. Typhimurium (LPS-T). Statistically significant differences for $p<0.001$ as compared to the control group. 
The analysis of the cell viability (MTT assay) demonstrated that a $24 \mathrm{~h}$ exposure to the low dose of LPS from studied serotypes of Salmonella spp. did not exert any toxic or proliferative effect on neuronal and non-neuronal DRG cells viability of DRG (Figure 6).

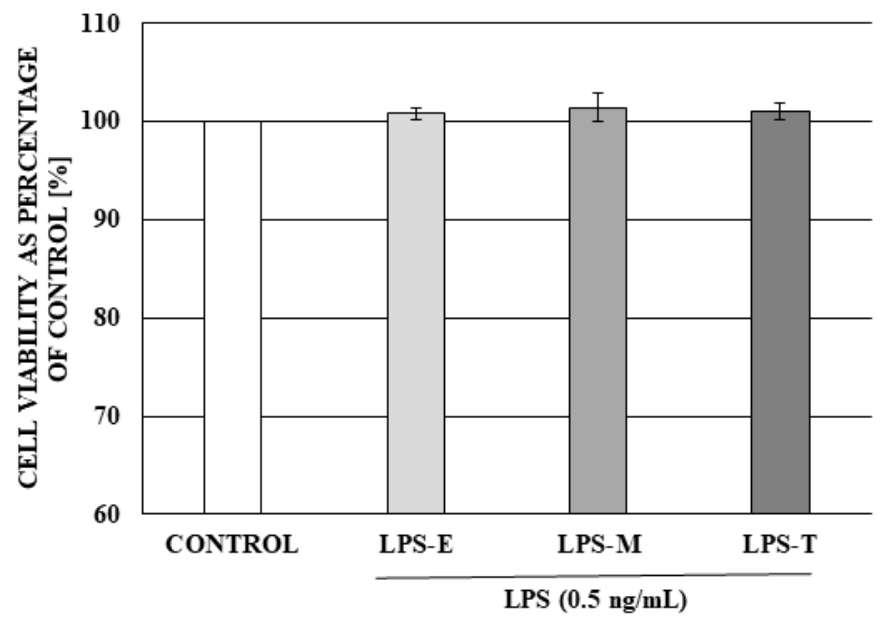

Figure 6. The effect of a low dose $(0.5 \mathrm{ng} / \mathrm{mL})$ of LPS from different serotypes of Salmonella spp: LPS from Salmonella Enteritidis (LPS-E), LPS from Salmonella Minnesota (LPS-M), LPS from Salmonella Typhimurium (LPS-T) on DRG cell viability. Cell viability was assessed using the MTT method. Data are presented as means of the percentage of the untreated control cells \pm SE $(n=4)$.

Representative examples of dorsal root ganglia (DRG) neurons supplying the ileocecal valve observed during the present study in the cell culture are visualised in Figures 7 and 8.

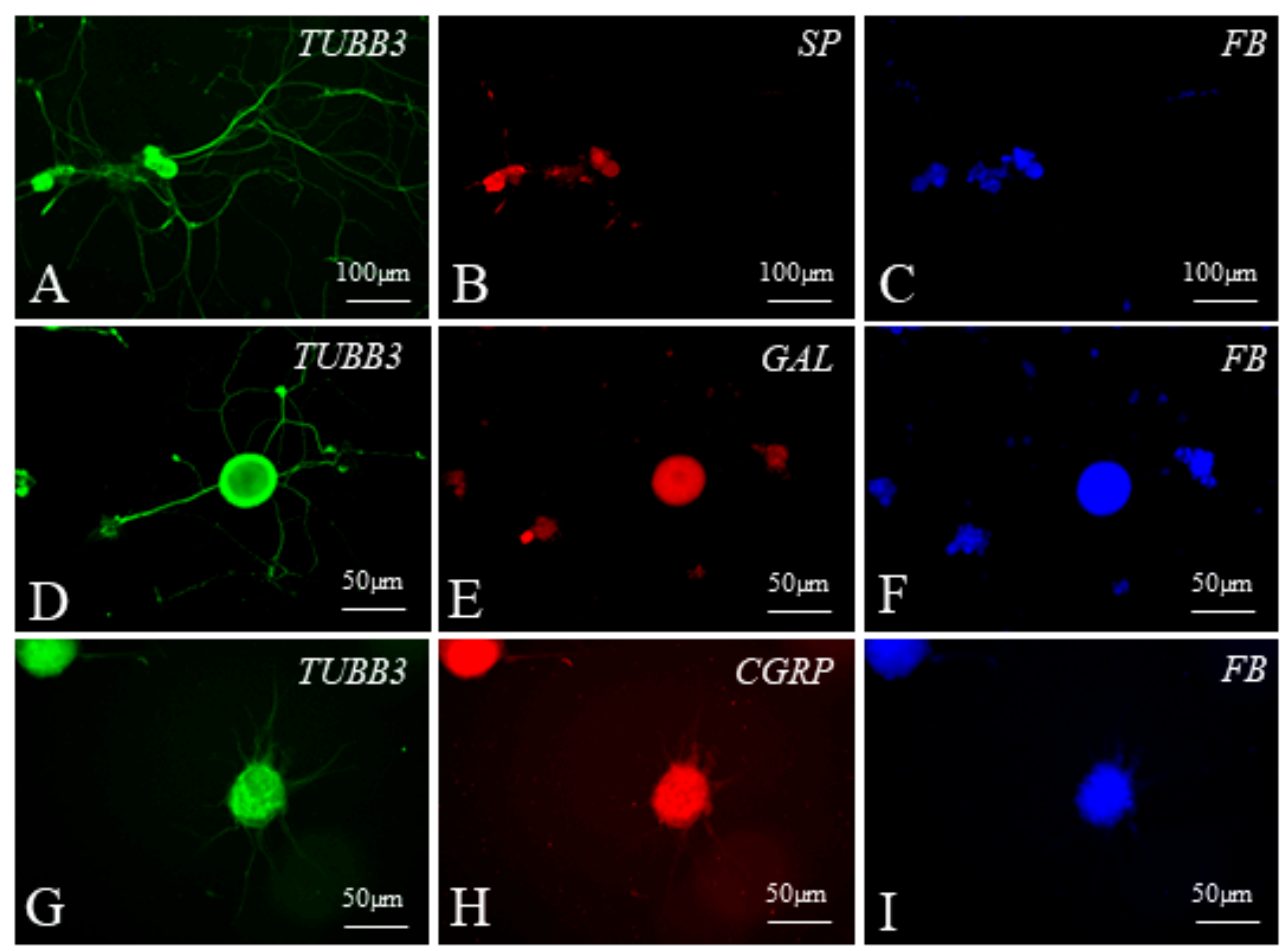

Figure 7. Examples of dorsal root ganglia (DRG) neurons supplying the ileocecal valve (FB-positive, blue) $(\mathbf{C}, \mathbf{F}, \mathbf{I})$, immunoreactive to tubulin (TUBB3 used here as a neuronal marker, green) $(\mathbf{A}, \mathbf{D}, \mathbf{G})$ and substance P (SP) (B), galanin (GAL) (E) or calcitonin gene-related peptide (CGRP) (H) in cell cultures of the control group. 


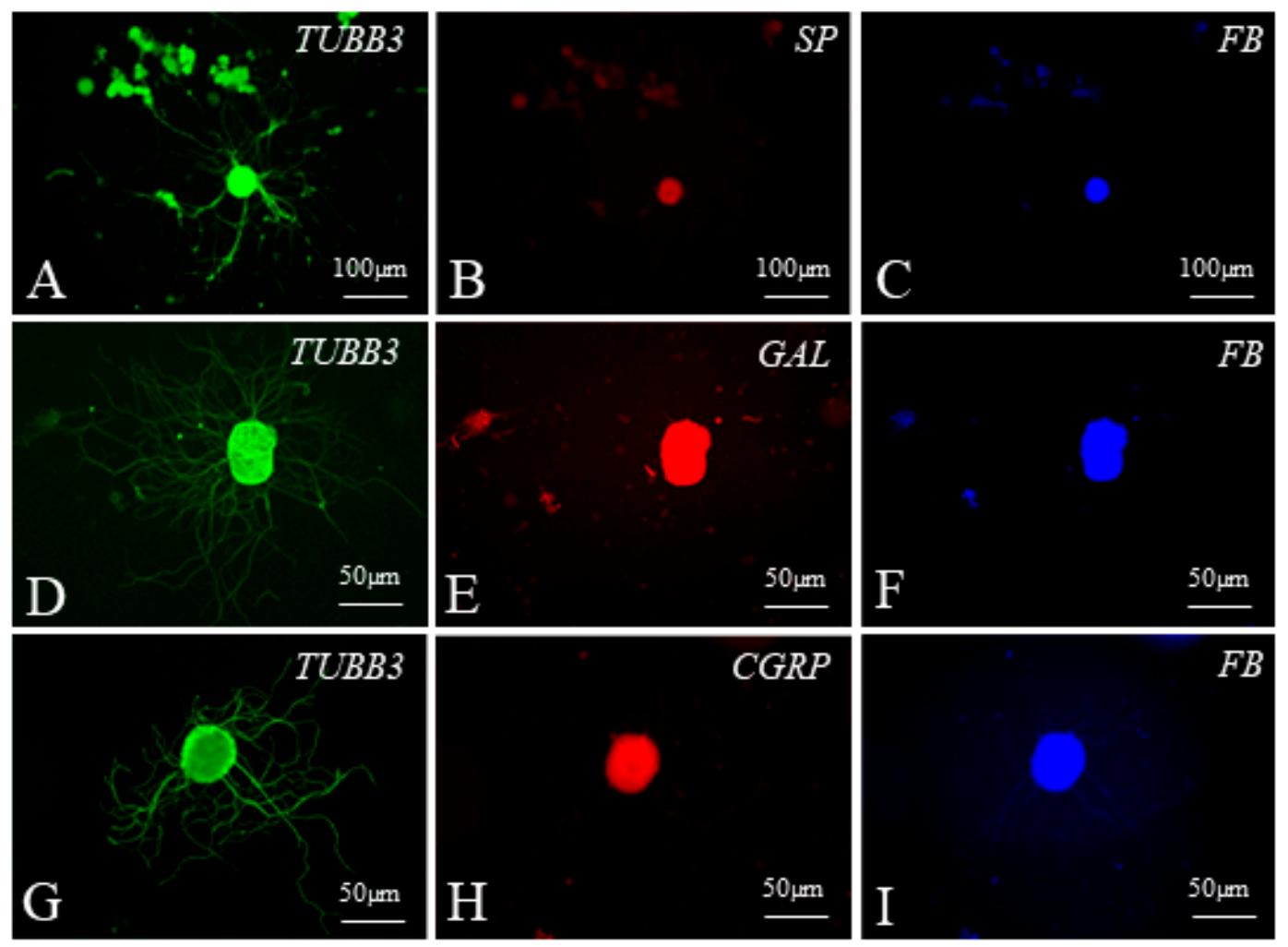

Figure 8. Examples of dorsal root ganglia (DRG) neurons supplying the ileocecal valve (FB-positive blue) $(\mathbf{C}, \mathbf{F}, \mathbf{I})$ immunoreactive to tubulin (TUBB3 used here as a neuronal marker, green) $(\mathbf{A}, \mathbf{D}, \mathbf{G})$ and substance P (SP) (B), galanin (GAL) (E), and calcitonin gene-related peptide (CGRP) (H) (all these substances in red) in cell cultures treated with lipopolysaccharides from Salmonella Enteritidis (A-C), Salmonella Typhimurium (D-F) and Salmonella Minnesota (G-I).

\section{Discussion}

The results obtained in this study indicate that the ICV, similar to other parts of the gastrointestinal tract, is supplied by neurons located in DRG [30]. Similar to previous studies, where DRG neuronal cells supplying the stomach, duodenum, ileum, and colon were described in various mammal species [30-33], observations made during the present investigations show that DRG plays a role in ICV sensory innervation in the domestic pig. On the other hand, the relatively low number of FB+ neurons observed in this study suggest that sensory components of the vagal nerve may play more important functions in the innervation of the ICV. This is according to the previous studies, where it was found that the network of processes derived from DRG neurons in the colon is more extensive than in the stomach and jejunum [30,32]. This is connected with the fact that branches of the vagal nerve supply the GI tract from the oesophagus to the proximal colon [34]. The majority of FB+ neuronal cells innervating the ICV investigated in this study were located in the thoracic and lumbar DRG, which is generally consistent with the distribution of previously described DRG neuronal cells supplying the small intestine.

Previous studies have shown that neuronal cells located in the DRG may contain (apart from typical substances involved in the sensory and pain stimuli conductions, such as SP and CGRP) a wide range of active neuronal factors, including GAL, CART peptide, vasoactive intestinal polypeptide, nitric oxide, somatostatin, and many others [35,36]. During the present study, the majority of DRG neurons supplying the ICV also contain SP and/or CGRP. SP is a member of the tachykinin family. It is a substance participating in sensory and pain stimuli conduction and has been observed in sensory neuronal cells and fibres in the central and peripheral nervous system of numerous species, including human [37-41]. It should be underlined that SP, besides sensory functions, may also participate in 
other various regulatory processes within the GI tract. In particular, it is known that SP regulates the intestinal motility and secretory activity [37], blood flow within the intestine and mesentery [42], as well immunological processes [43].

The second important substance participating in sensory and pain conduction, which has been observed in sensory neurons supplying the ICV, is CGRP. This peptide, similarly to SP, has been described in various central and peripheral sensory nervous structures of a wide range of mammals [44,45]. Within the digestive tract of some species, CGRP is considered to be a marker of intrinsic primary afferent neurons, which belong to the enteric nervous system and are a component of short intramural reflexes taking place without the central nervous system [46]. CGRP within the GI tract is also involved in regulatory processes connected with blood flow, secretory activity, and the absorption of nutrients [47,48]. Moreover, this peptide takes part in the protection of the intestinal mucosal layer against injuries and regulates intestinal motility [49].

The third substance studied in this investigation-GAL-is a not classical factor taking part in sensory or pain stimuli conduction. Nevertheless, the presence of GAL has been described in sensory neuronal structures supplying various internal organs [50,51]. It is known that GAL takes part in the regulation of other neurotransmitters by acting on the ion channels within the membrane of neuronal cells $[52,53]$. Besides sensory conduction, GAL in the GI system regulates the intestinal motility and secretory activity and the character of processes regulated by GAL clearly depends on the animal species and the fragment of the intestine [54,55].

In the light of the previous investigations, it is known that all neuronal factors studied during this experiment participate in regulatory processes not only under physiological conditions, but are also involved in pathological mechanisms of various diseases and intoxications with a wide range substances. Evidence of this includes changes in the expression of SP, CGRP, and GAL both in the enteric nervous system and extrinsic neuronal cells supplying the intestine under the influence of inflammatory processes, neuronal damage, intoxication with mycotoxins, and other toxicological substances and many other pathological stimuli $[38,56]$. For SP, these changes may be connected with neuroprotective properties and the participation of this peptide in inflammatory processes [38]. Namely, it is known that SP acting on lymphocytes and macrophages stimulates the secretion of pro-inflammatory cytokines, including IL-1 and TNF- $\alpha$ - the most important inflammatory mediator [37,43]. In turn, GAL is known from neuroprotective functions in the central and peripheral nervous system, which have primarily been described during brain injuries and neurodegenerative diseases [57]. Moreover, GAL (contrary to SP) plays an anti-inflammatory role by enhancing synthesis and secretion of IFN- $\gamma$ and IL-12/23 while simultaneously decreasing the levels of TNF- $\alpha$ and IL-1 $\beta$ [58]. However, CGRP, whose role in intestinal diseases has not been fully elucidated, may inhibit the expression of TNF- $\alpha$ and IL-1 $\beta$ and take part in mechanisms connected with the development of diarrhoea [59]. On the other hand, the participation of CGRP in neuroprotective processes within the innervation of the intestine, despite changes in CGRP expression under various pathological stimuli [60], has not yet been confirmed.

Changes in the immunoreactivity of DRG neurons observed during the present study probably result from the above-mentioned functions of neuronal factors under the impact of LPS. These changes may be connected with neuroprotective and/or adaptive processes used to maintain homeostasis within the nervous tissues These may result from the pro-inflammatory activity of LPS, described in the previous investigations. In particular, it is known that one of the components of LPS - lipid A-strongly induces synthesis and the secretion of pro-inflammatory substances [61]. However, a more likely cause of the observed changes is the direct impact of LPS on neuronal cells. It should be underlined that this impact in the light of the previous studies is not clear and depends on LPS dose. On the one hand, the neurotoxic activity of LPS is relatively well-known. Previous investigations have described the involvement of this substance in neurodegenerative processes in various parts of the nervous system [62-64]. Moreover, LPS is used as a factor inducing experimental Parkinson's disease in rodents [65-68]. On the other hand, it has been shown that low doses of LPS are essential to 
promote the survival of enteric and hippocampal neurons. Anitaha et al. [69] found that for enteric neuronal survival, microbial-neuronal interaction is essential and a low dose of LPS is essential to maintain neuronal survival, although at higher doses LPS results in neuronal toxicity. Low dose LPS treatment $(10 \mathrm{ng} / \mathrm{mL})$ promoted enteric neuronal survival through the activation of NF-KB and TLR4. None of our studied serotypes of Salmonella spp. influenced the neuron counts and furthermore, we saw that neurons treated with $0.5 \mu \mathrm{g} / \mathrm{mL}$ LPS have longer and denser neurites compared to the control group. This is only a subjective observation which has not been supported by any analysis of neuron morphology. Perhaps, hypothetically, it was in connection with the role of glial cells, but we did not study it because it was not the intended goal of our study. Additionally, LPS in a low dose has been shown to promote the survival of hippocampal neurons through increased expression of a granulocyte colony-stimulating factor [70]. But, in the central nervous system (CNS), hippocampal neurogenesis and neurological functions were attenuated by lipopolysaccharide-induced TLR4 activation [71]. Moreover, some studies have shown the protective effect of LPS pre-treatment [72] and endotoxin tolerance provides (enhances) the ischemic resistance of neuronal cells [73]. In contrast, Chen et al. [74] reported that pre-conditioning with a super-low or low dose of LPS exacerbates sepsis mortality. Further studies may be required to find consistent issues to combine the different results of various studies.

\section{Materials and Methods}

The present study consisted of two experiments conducted on nine immature sows of the Pietrain $\times$ Duroc breed. All animals were kept in standard laboratory conditions and fed with complete feeding stuff appropriate to the age and species of animals for two weeks prior to the experiment in order to allow adaptation to the new environment. The experiments took place when the pigs were 8-9 weeks of age with body weights of $16-18 \mathrm{~kg}$. Both administration of the drugs and the performance of surgical procedures were performed by a veterinary doctor (DVM, Ph.D.). All procedures in the experiment were approved by the Local Ethical Commission of Experiments on Animals in Olsztyn (decision number 73/2015 from 29 September 2015).

\subsection{Experiment No. 1: Localization and Neurochemical Characterization of Neurons Located in the Dorsal Root Ganglia and Supplying the ICV}

The first experiment was conducted to study the sensory neurons located in dorsal root ganglia and supplying the ileocecal valve (ICV). For this part of the experiment, five pigs were used.

\subsubsection{Surgical Procedures Surgery}

Before surgical procedures, five animals were pre-medicated using the method previously described by Mikolajczyk [75] with intramuscular injection of atropine (Atropinum Sulfuricum Polfa Warszawa S.A., Warszawa, Poland, $0.035 \mathrm{mg} / \mathrm{kg}$ b.w.), ketamine (Bioketan, Vetoquinol Biowet Sp. z o.o., Poland and Vetoquinol S.A., Lure, France, $7.0 \mathrm{mg} / \mathrm{kg}$ b.w.), and medetomidine (Cepetor, CP-Pharma Handelsges mbH, Burgdorf, Germany, $0.063 \mathrm{mg} / \mathrm{kg}$ b.w.). After $15 \mathrm{~min}$. the animals were subjected to the general anaesthesia with propofol (Scanofol, NORBROOK, Newry, Northern Ireland, IRL.PN, $4.5 \mathrm{mg} / \mathrm{kg}$ b.w. given intravenously) and median laparotomy. During the transaction surgery procedure, a conventional midline incision of the abdominal wall was made. The cecum and ileum were identified and the ICV was isolated from the abdominal cavity. The ICV was injected with $50 \mu \mathrm{L}$ of a $5 \%$ aqueous solution of the fluorescence retrograde neuronal tracer fast blue (FB; EMSChemie $\mathrm{GmbH}$, Groß-Umstadt, Germany, ten injections, $5 \mu \mathrm{L}$ each) using a Hamilton syringe equipped with a 26-gauge needle. Close attention was paid to avoiding any contamination of the surrounding tissues with FB due to the hydrostatic leakage from the injection canal. To avoid leakage, the needle was left in each site of FB injection for up to a minute. The peritoneum with the transverse abdominal muscles, the internal and external abdominal oblique muscles, and the cutaneous muscle with subcutaneous fascia were closed in a simple continuous pattern. The skin was closed in a subcuticular pattern. 


\subsubsection{Sample Collection and Processing}

After three weeks, the animals were again pre-medicated (as described above) and euthanized with pentobarbital (Morbital, Biowet Puławy Sp. z o.o, Poland, $60-70 \mathrm{mg} / \mathrm{kg}$ b.w., given intravenously). After death, the thoracic, lumbar, and sacral dorsal root ganglia were collected. Ganglia were fixed in $4 \%$ buffered paraformaldehyde ( $\mathrm{pH} 7.4$ ) for $30 \mathrm{~min}$. and rinsed in phosphate buffer for three days (at $40{ }^{\circ} \mathrm{C}$ ). They then added a $18 \%$ sucrose solution and stored it for least three weeks at $40{ }^{\circ} \mathrm{C}$. After this period, the ganglia were frozen at $-20^{\circ} \mathrm{C}$ and cut into $10 \mu \mathrm{m}$-thick sections using a cryostat (HM 525, Microm International, Germany).

\subsubsection{Immunofluorescence Procedures with Counting Neurons}

The sections were subjected to examination for the presence of neurons containing FB using a fluorescence Olympus BX51 microscope equipped with an appropriate filter set. Sections with FB-positive cells were subjected to typical single immunofluorescence technique by the method described previously by Gonkowski et al. [76]. Basically, during this method, fragments of DRG were subjected to (1) drying at room temperature (rt) for $1 \mathrm{~h}$; (2) "blocking" in the solution containing $10 \%$ normal goat serum, $0.1 \%$ bovine serum albumin, $0.01 \%$ NaN3, Triton X-100 and thimerozal in PBS for $1 \mathrm{~h} \mathrm{(rt);} \mathrm{(3)} \mathrm{incubation} \mathrm{with} \mathrm{antibodies} \mathrm{directed} \mathrm{towards} \mathrm{SP,} \mathrm{CGRP} \mathrm{or} \mathrm{galanin} \mathrm{(GAL)} \mathrm{(overnight;}$ rt, in a humid chamber); (4) incubation with secondary antibodies conjugated with appropriate fluorochromes (alexa fluor 594 or 488) to visualise the complexes "antigen-primary antibody". The specifications and working dilution of primary and secondary antisera are presented in Table 1.

Table 1. List of antisera and reagents used in immunohistochemical investigations.

\begin{tabular}{|c|c|c|c|c|}
\hline \multicolumn{5}{|c|}{ Primary antibodies } \\
\hline Antigen & Code & Species & Working dilution & Supplier \\
\hline CGRP & AB5920 & Rabbit & 1:1600 & Chemicon Int Temecula, OH, USA \\
\hline GAL & $\mathrm{T}-5036$ & Guinea Pig & 1:2000 & Peninsula San Carlos, CA, USA \\
\hline $\mathrm{SP}$ & $8450-0505$ & Rat & 1:1000 & $\begin{array}{c}\text { Bio-Rad (AbD Serotec), } \\
\text { Kidlington, UK }\end{array}$ \\
\hline \multicolumn{5}{|c|}{ Secondary antibodies } \\
\hline & Reagents & & Working dilution & Supplier \\
\hline \multicolumn{3}{|c|}{ Alexa fluor 546 donkey anti-rabbit IgG } & 1:1000 & Invitrogen Carlsbad, CA, USA \\
\hline \multicolumn{3}{|c|}{ Alexa fluor 546 donkey anti-guinea pig IgG } & 1:1000 & Invitrogen \\
\hline \multicolumn{3}{|c|}{ Alexa fluor 488 goat anti-rat IgG } & 1:1000 & Invitrogen \\
\hline
\end{tabular}

To confirm the specificity of the method routine standard controls, such as pre-absorption of the neuropeptide antisera with appropriate antigen, omission and replacement of primary antisera by non-immune sera were performed. To determine the percentage of neurons supplying the ICV immunoreactive to SP, CGRP, or GAL, at least $50 \mathrm{FB}+$ neuronal cells from each animal were evaluated for the presence of the particular neuronal factors. This relatively low number of neurons included in the experiment was caused by the relatively small number of all neuronal cells supplying the ICV. The obtained data was pooled, expressed as means \pm SD.

\subsection{Experiment No. 2: Culturing of Primary Sensory Neurons and Various Serotypes of Salmonella spp.}

The second experiment conducted during this investigation consisted of a study of the influence of a low dose $(0.5 \mathrm{ng} / \mathrm{mL}[77,78]$ of LPS from various types of Salmonella spp. serotypes: LPS from Salmonella enterica subsp. enterica serotype Enteritidis (L7770 Sigma), LPS from Salmonella enterica subsp. enterica serotype Minnesota (L4641 Sigma), LPS from Salmonella enterica subsp. enterica 
serotype Typhimurium (L6143 Sigma) on the neurochemical characterization of neurons located in DRG. Thus, during the in vitro experiment, four groups of cultures were used: control, Enteritidis (LPS-E), Minnesota (LPS-M), and Typhimurium (LPS-T). For this part of the experiment, four pigs were used.

\subsubsection{Sample Collection and Processing}

After three weeks, all animals were again pre-medicated and subjected to general anaesthesia conducted as described above. During anaesthesia, the left and right thoracic (Th7-Th13) ganglia and lumbar (L1-L4) ganglia were exposed. For DRG exposure, an incision was made in the skin of the dorsal midline. The superficial muscular fascia was incised and the paraspinal muscles separated by a combination of sharp and blunt dissection, exposing the lumbar and thoracic vertebrae. A rongeur was used to remove bone fragments of spinal nerves as well as the intervertebral foramina from which they emerge, which were exposed along with particular ganglia. The animals were then euthanized with pentobarbital (in the above-described manner).

DRG were removed and transferred into cold RPMI 1640 W/HEPES W/GLUTAMAX-I medium (cat. no. 72400021, Life Technologies Polska Sp. z.o.o.; Warszawa, Poland) and antibiotic and antimycotic (cat. no. 15240062, Life Technologies Polska Sp. z.o.o.; Poland).

\subsubsection{Cell Culture and Treatments}

Cell cultures were prepared as described previously [79,80]. Briefly, following removal of connective tissue, DRG were incubated in collagenase (cat. no. 17100017, Life Technologies Polska Sp. z.o.o.; Poland) for $60 \mathrm{~min}$ followed by 0.5\% trypsin/EDTA (15400054, Life Technologies Polska Sp. z.o.o.; Poland). Neurons were dissociated by passages through a fire-polished Pasteur pipette and centrifuged at a low speed (10 $\mathrm{min}, 700 \mathrm{rpm})$. After final centrifugation, the pellet was suspended with TNB 100TM medium (cat. no. F8023; Biochrom AG, Berlin, Germany) containing: antibiotic and antimycotic and protein-lipid complex TM (cat. no. F8820; Biochrom AG, Germany). Equal volumes $(50 \mu \mathrm{L})$ containing DRG neurons were seeded on glass coverslip (12 $\mathrm{mm}$ in diameter) coated with poly-D-lysine ( $0.01 \%$ solution; cat. no. P7280; Aldrich)/laminin (1 mg/mL L-2020, Sigma) placed in six-well multi-dishes (cat. no. 353046; BD Biosciences; Franklin Lakes, NJ, USA) at a density of 50-70 per glass. Cultures were cultivated in TNB medium $1 \mathrm{~mL}$ per well with $5 \mathrm{ng} / \mathrm{mL}$ nerve growth factor beta (NGF; N1408; Sigma Aldrich; Berlin, Germany) to maintain the survival of neurons [81]. After $36 \mathrm{~h}$ incubation at $37^{\circ} \mathrm{C}$ in $5 \% \mathrm{CO}_{2}$, the medium was replaced with fresh medium in the control and with fresh medium with the addition of $0.5 \mathrm{ng} / \mathrm{mL}$ LPS from $S$. Enteritidis, LPS from $S$. Minnesota (L4641 Sigma), LPS from S. Typhimurium (L6143 Sigma) in the LPS-treated group. We decided to use a $36 \mathrm{~h}$ cell primary neuron culture because extensive neurite outgrowth was observed after $24 \mathrm{~h}$ of culture [82].

\subsubsection{Immunocytochemical Labelling}

After $60 \mathrm{~h}$ (including $24 \mathrm{~h}$ of culture with the addition of LPS to the media) in culture, neurons were fixed with $4 \%$ paraformaldehyde for $20 \mathrm{~min}$, permeabilised with $0.01 \%$ Triton X-100 (X100-100ML; Sigma Aldrich; Germany) in PBS (P5493; Sigma Aldrich; Germany) for 5 min and blocked with blocking buffer (10\% goat serum in PBS) for $30 \mathrm{~min}$. DRG neurons were incubated with primary antibodies against substance P (8450-0004; AbD Serotec; Regensburg, Germany; 1:3000), calcitonin gene-related peptide (AB43873; Abcam; Cambridge, UK; 1:18,000), galanin (AB5909; Merck Millipore; Burlington, MA, USA; 1:16,400) and neuron-specific $\beta$-III tubulin (MAB1195; R\&D Systems; Minneapolis, MN, USA; 1:1000) diluted in blocking buffer for $1 \mathrm{~h}$ at room temperature and then incubated with secondary Alexa-555- and Alexa-488-conjugated antibody (A31572; A-11001, Invitrogen, Carlsbad, CA, USA; 1:1000) for $60 \mathrm{~min}$ at RT. We stained all DRG neurons (FB-labelled and FB-unlabelled) using neuron-specific $\beta$-III tubulin [83] in co-localization with CGRP, SP, and GAL [84]. 


\subsubsection{Counting Cultured Neurons}

Both FB-labelled neurons projecting to the ICV and unlabelled neurons projecting to other organs (also large extent, the colon) [85] were counted.

The experiment in vitro was performed in duplicate with two replicate wells (four coverslips in one well, i.e., eight coverslips per one animal) for each group of cultures (control, Enteritidis, Minnesota and Typhimurium). The number of neurons in the control and after LPS treatment group were counted and then expressed in percentage. FB-traced neurons were identified in the cell cultures by their blue fluorescence under the UV illumination using fluorescence Olympus BX51 microscope (V1 module, excitation range $330-385 \mathrm{~nm}$ and barrier filter at $420 \mathrm{~nm}$ ). The number of $\beta$-III tubulin neurons in all studied groups (control and with the addition of LPS to the medium) was considered as the number of total neurons $(100 \%)$. The number of neurons containing studied substances ( $\beta$-III tubulin, CGRP, GAL, and SP) in intact and LPS-treated group was quantified using a fluorescent Olympus BX51 microscope (Shinjuku, Tokyo, Japan) equipped with an appropriate filter sets for Alexa 488 (B1 module, excitation filter 450-480 nm) and Alexa 555 (G1, excitation filter 510-550 nm). Microphotographs were acquired using $20 \times$ objectives and a PC equipped with a CCD camera operated by Cell Sens Dimension image analysis software (Olympus, Warsaw, Poland).

\subsubsection{MTT Assay}

To determine the cell viability by MTT assay, DRG cells were prepared as described before using six well multi-dishes with glass coverslips and seeded in a 96-well plate (CytoOne cat no: CC7682-7596). After $36 \mathrm{~h}$ incubation at $37^{\circ} \mathrm{C}$ in $5 \% \mathrm{CO}_{2}$ the cells were treated with $0.5 \mathrm{ng} / \mathrm{mL}$ LPS from $S$. Enteritidis, LPS from S. Minnesota, and LPS from S. Typhimurium or tested without LPS (control group) and incubated at $37{ }^{\circ} \mathrm{C}$ in $5 \% \mathrm{CO}_{2}$ for $24 \mathrm{~h}$. After incubation, $50 \mu \mathrm{L}$ MTT (Thiazolyl Blue Tetrazolium Bromide $5 \mathrm{mg} / \mathrm{mL}$, M5655 Sigma) was added and the plates were incubated at $37{ }^{\circ} \mathrm{C}$ in $5 \% \mathrm{CO}_{2}$ for $4 \mathrm{~h}$. At the end of the incubation period, the supernatants were removed, and $100 \mu \mathrm{L}$ of dimethyl sulfoxide (DMSO 34943, Sigma) was added to each well to enable the release of the blue reaction product-formazan. The absorbance at $570 \mathrm{~nm}$ was read on a microplate reader Infinite 200 (Tecan) and the results were expressed as a percentage of the absorbance measured in control cells and in the LPS-treated culture.

\subsection{Statistical Analysis}

All data were expressed as the mean \pm standard deviation (SD) from independent experiments performed using five animals in the experiment $1(n=5)$ and four animals in experiment $2(n=4)$. Statistical analysis was determined using one-way analysis of variance (ANOVA) followed by Tukey's test for multiple comparisons (Statistica software / version 13.1 /StatSoft, Cracow, Poland). P values less than 0.05 were considered significant.

\section{Conclusions}

To sum up, the results obtained during the present study have shown that sensory processes supplying the ICV may derive from neurons located in DRG from neuromers Th7 to L4. The ICV sensory neurons contained SP, CGRP, and GAL. Moreover, it has been shown that the dose of LPS used in the in vitro study did not change the number of DRG neurons from neuromers Th7 to L4 supplying the ICV and other organs and tissues, but influenced their neurochemical characterization. The observed changes clearly depended on the bacterial serotype of LPS. This is proof that structural differences of LPS - not only between bacterial species, but also within particular serotypes of one species-result in varied impact on the nervous system. Moreover, the obtained results have shown that SP and GAL, contrary to CGRP, are involved in the processes connected with the impact of LPS. Changes in the expression of these substances may result from the direct influence of LPS on the nervous structures and/or pro-inflammatory activity of LPS. However, the explanation of the exact 
mechanisms connected with LPS-induced fluctuations in neurochemical characterization of DRG neurons requires further study.

Author Contributions: Conceptualization, A.M. (A.M. conceived and designed the study); Methodology and investigation in the experiment no. 1, A.M. and S.G.; Methodology and investigation in the experiment no. 2, A.M., S.G. and A.K.; Data Analysis, A.M.; Interpretation of the results, A.M.; Resources, A.M.; Writing the manuscript, A.M.; Visualization and analysis of microscopic images A.M. and S.G.

Funding: This research was supported by the statutory grant No. 25.610.001-300 from the Faculty of Medical Sciences, the University of Warmia and Mazury in Olsztyn in Poland.

Acknowledgments: This study was supported by the statutory grant No. 25.610.001-300, Faculty of Medical Sciences, the University of Warmia and Mazury in Olsztyn, Poland.

Conflicts of Interest: The authors declare no conflict of interest.

\section{References}

1. Furness, J.B. Types of neurons in the enteric nervous system. J. Auton. Nerv. Syst. 2000, 81, 87-96. [CrossRef]

2. Majewski, M.; Bossowska, A.; Gonkowski, S.; Wojtkiewicz, J.; Brouns, I.; Scheuermann, D.W.; Adriaensen, A.; Timmermans, J.P. Neither axotomy nor target-tissue inflammation changes the NOS- or VIP-synthesis rate in distal bowel-projecting neurons of the porcine inferior mesenteric ganglion (IMG). Folia Histochemica et Cytobiologica 2002, 40, 151-152. [PubMed]

3. Skobowiat, C.; Gonkowski, S.; Calka, J. Phenotyping of sympathetic chain ganglia (SChG) neurons in porcine colitis. J. Vet. Med. Sci. 2010, 72, 1269-1274. [CrossRef] [PubMed]

4. Makowska, K.; Gonkowski, S. The Influence of Inflammation and Nerve Damage on the Neurochemical Characterization of Calcitonin Gene-Related Peptide-Like Immunoreactive (CGRP-LI) Neurons in the Enteric Nervous System of the Porcine Descending Colon. Int. J. Mol. Sci. 2018, 19, 548. [CrossRef] [PubMed]

5. Furness, J.B.; Callaghan, B.P.; Rivera, L.R.; Cho, H.J. The enteric nervous system and gastrointestinal innervation: Integrated local and central control. Adv. Exp. Med. Biol. 2014, 817, 39-71. [PubMed]

6. Avetisyan, M.; Schill, E.M.; Heuckeroth, R.O. Building a second brain in the bowel. J. Clin. Investig. 2015, 125, 899-907. [CrossRef] [PubMed]

7. Browning, K.N.; Travagli, R.A. Central nervous system control of gastrointestinal motility and secretion and modulation of gastrointestinal functions. Compr. Physiol. 2014, 4, 1339-1368. [PubMed]

8. Rytel, L.; Calka, J. Acetylsalicylic acid-induced changes in the chemical coding of extrinsic sensory neurons supplying the prepyloric area of the porcine stomach. Neurosci. Lett. 2016, 617, 218-224. [CrossRef] [PubMed]

9. Dorofeeva, A.A.; Panteleev, S.S.; Makarov, F.N. Involvement of the sacral parasympathetic nucleus in the innervation of the descending colon and rectum in cats. Neurosci. Behav. Physiol. 2009, 39, 207-210. [CrossRef] [PubMed]

10. Rytel, L.; Całka, J. Neuropeptide profile changes in sensory neurones after partial prepyloric resection in pigs. Ann. Anat. 2016, 206, 48-56. [CrossRef] [PubMed]

11. Phillips, S.F.; Camilleri, M. The ileocecal area and the irritable bowel syndrome. Gastroenterol. Clin. N. Am. 1991, 20, 297-311.

12. Cserni, T.; Paran, S.; Kanyari, Z.; O'Donnell, A.M.; Kutasy, B.; Nemeth, N.; Puri, P. New insights into the neuromuscular anatomy of the ileocecal valve. Anat. Rec. 2009, 292, 254-261. [CrossRef] [PubMed]

13. Palmisano, S.; Silvestri, M.; Troian, M.; Germani, P.; Giudici, F.; de Manzini, N. Ileocaecal valve syndrome after surgery in adult patients: Myth or reality? Color. Dis. 2017, 19, e288-e295. [CrossRef] [PubMed]

14. Kaur, U.; Goyal, N.; Gupta, M. Disposition of muscularis propria and nerve elements in the lip of the ileocaecal valve. Nepal Med. Coll. J. 2005, 7, 125-128. [PubMed]

15. Cserni, T.; Paran, S.; Puri, P. New hypothesis on the pathogenesis of ileocecal intussusception. J. Pediatr. Surg. 2007, 42, 1515-1519. [CrossRef] [PubMed]

16. Maciel, B.M.; Passos, R.; Sriranganathan, N. Salmonella enterica: Latency. In Current Topics in Salmonella and Salmonellosis; Mares, M., Ed.; IntechOpen: Rijeka, Croatia, 2017; pp. 43-58, ISBN 978-953-51-3066-6.

17. Guo, S.; Al-Sadi, R.; Said, H.M.; Ma, T.Y. Lipopolysaccharide causes an increase in intestinal tight junction permeability in vitro and in vivo by inducing enterocyte membrane expression and localization of TLR-4 and CD14. Am. J. Pathol. 2013, 182, 375-387. [CrossRef] [PubMed] 
18. Ramachandran, G. Gram-positive and gram-negative bacterial toxins in sepsis: A brief review. Virulence 2014, 5, 213-218. [CrossRef] [PubMed]

19. Mikołajczyk, A.; Makowska, K. Cocaine- and amphetamine-regulated transcript peptide (CART) in the nerve fibers of the porcine gallbladder wall under physiological conditions and after Salmonella Enteritidis lipopolysaccharides administration. Folia Morphol. 2017, 76, 596-602. [CrossRef] [PubMed]

20. Mikołajczyk, A.; Gonkowski, S.; Złotkowska, D. Modulation of the Main Porcine Enteric Neuropeptides by a Single Low-Dose of Lipopolysaccharide (LPS) Salmonella Enteritidis. Gut Pathog. 2017, 9, 73. [CrossRef] [PubMed]

21. Makowska, K.; Mikolajczyk, A.; Calka, J.; Gonkowski, S. Neurochemical characterization of nerve fibers in the porcine gallbladder wall under physiological conditions and after the administration of Salmonella Enteritidis lipopolysaccharides (LPS). Toxicol. Res. 2018, 7, 73-83. [CrossRef] [PubMed]

22. Reyes, R.E.; González, C.; Jiménez, R.C.; Ortiz, M.C.; Andrade, A.A. Mechanisms of O-Antigen Structural Variation of Bacterial Lipopolysaccharide (LPS). In The Complex World of Polysaccharides; Karunaratne, D.N., Ed.; INTECH Open Access: Kelaniya, Sri Lanka, 2012; pp. 71-98, ISBN 978-953-51-0819-1. [CrossRef]

23. Pieterse, E.; Rother, N.; Yanginlar, C.; Hilbrands, L.B.; van der Vlag, J. Neutrophils Discriminate between Lipopolysaccharides of Different Bacterial Sources and Selectively Release Neutrophil Extracellular Traps. Front. Immunol. 2016, 7, 484. [CrossRef] [PubMed]

24. Steimle, A.; Autenrieth, I.B.; Frick, J.S. Structure and function: Lipid A modifications in commensals and pathogens. Int. J. Med. Microbiol. 2016, 306, 290-301. [CrossRef] [PubMed]

25. Vatanen, T.; Kostic, A.D.; D’Hennezel, E.; Siljander, H.; Franzosa, E.A.; Yassour, M.; Kolde, R.; Vlamakis, H.; Arthur, T.D.; Hämäläinen, A.M.; et al. Variation in Microbiome LPS Immunogenicity Contributes to Autoimmunity in Humans. Cell 2016, 165, 842-853. [CrossRef] [PubMed]

26. Khan, M.M.; Ernst, O.; Sun, J.; Fraser, I.D.C.; Ernst, R.K.; Goodlett, D.R.; Nita-Lazar, A. Mass Spectrometry-based Structural Analysis and Systems Immunoproteomics Strategies for Deciphering the Host Response to Endotoxin. J. Mol. Biol. 2018, 430, 2641-2660. [CrossRef] [PubMed]

27. Pulendran, B.; Kumar, P.; Cutler, C.W.; Mohamadzadeh, M.; Van Dyke, T.; Banchereau, J. Lipopolysaccharides from distinct pathogens induce different classes of immune responses in vivo. J. Immunol. 2001, 167, 5067-5076. [CrossRef] [PubMed]

28. Nedrebø, T.; Reed, R.K. Different serotypes of endotoxin (lipopolysaccharide) cause different increases in albumin extravasation in rats. Shock 2002, 18, 138-141. [CrossRef] [PubMed]

29. Verma, N.; Rettenmeier, A.W.; Schmitz-Spanke, S. Recent advances in the use of Sus scrofa (pig) as a model system for proteomic studies. Proteomics 2011, 11, 776-793. [CrossRef] [PubMed]

30. Chen, B.N.; Olsson, C.; Sharrad, D.F.; Brookes, S.J. Sensory innervation of the guinea pig colon and rectum compared using retrograde tracing and immunohistochemistry. Neurogastroenterol. Motil. 2016, 28, 1306-1316. [CrossRef] [PubMed]

31. Ohmori, Y.; Atoji, Y.; Saito, S.; Ueno, H.; Inoshima, Y.; Ishiguro, N. Differences in extrinsic innervation patterns of the small intestine in the cattle and sheep. Auton. Neurosci. 2012, 167, 39-44. [CrossRef] [PubMed]

32. Zalecki, M. Extrinsic primary afferent neurons projecting to the pylorus in the domestic pig-Localization and neurochemical characteristics. J. Mol. Neurosci. 2014, 52, 82-89. [CrossRef] [PubMed]

33. Spencer, N.J.; Zagorodnyuk, V.; Brookes, S.J.; Hibberd, T. Spinal afferent nerve endings in visceral organs: Recent advances. Am. J. Physiol. Gastrointest. Liver Physiol. 2016, 311, 1056-1063. [CrossRef] [PubMed]

34. Matteoli, G.; Boeckxstaens, G.E. The vagal innervation of the gut and immune homeostasis. Gut 2013, 62, 1214-1222. [CrossRef] [PubMed]

35. Bossowska, A.; Crayton, R.; Radziszewski, P.; Kmiec, Z.; Majewski, M. Distribution and neurochemical characterization of sensory dorsal root ganglia neurons supplying porcine urinary bladder. J. Physiol. Pharmacol. 2009, 4, 77-81.

36. Guić, M.M.; Kosta, V.; Aljinović, J.; Sapunar, D.; Grković, I. Characterization of spinal afferent neurons projecting to different chambers of the rat heart. Neurosci. Lett. 2010, 469, 314-318. [CrossRef] [PubMed]

37. Shimizu, Y.; Matsuyama, H.; Shiina, T.; Takewaki, T.; Furness, J.B. Tachykinins and their functions in the gastrointestinal tract. Cell. Mol. Life Sci. 2008, 65, 295-311. [CrossRef] [PubMed] 
38. Gonkowski, S. Substance $P$ as a neuronal factor in the enteric nervous system of the porcine descending colon in physiological conditions and during selected pathogenic processes. Biofactors 2013, 39, 542-551. [CrossRef] [PubMed]

39. Mistrova, E.; Kruzliak, P.; Chottova Dvorakova, M. Role of substance P in the cardiovascular system. Neuropeptides 2016, 58, 41-51. [CrossRef] [PubMed]

40. Chi, G.; Huang, Z.; Li, X.; Zhang, K.; Li, G. Substance P Regulation in Epilepsy. Curr. Neuropharmacol. 2018, 16, 43-50. [CrossRef] [PubMed]

41. Lénárd, L.; László, K.; Kertes, E.; Ollmann, T.; Péczely, L.; Kovács, A.; Kállai, V.; Zagorácz, O.; Gálosi, R.; Karádi, Z. Substance P and neurotensin in the limbic system: Their roles in reinforcement and memory consolidation. Neurosci. Biobehav. Rev. 2018, 85, 1-20. [CrossRef] [PubMed]

42. De Fontgalland, D.; Wattchow, D.A.; Costa, M.; Brookes, S.J. Immunohistochemical characterization of the innervation of human colonic mesenteric and submucosal blood vessels. Neurogastroenterol. Motil. 2008, 20, 1212-1226. [CrossRef] [PubMed]

43. Zhao, D.; Kuhnt-Moore, S.; Zeng, H.; Pan, A.; Wu, J.S.; Simeonidis, S.; Moyer, M.P.; Pothoulakis, C. Substance P-stimulated interleukin-8 expression in human colonic epithelial cells involves Rho family small GTPases. Biochem. J. 2002, 368, 665-672. [CrossRef] [PubMed]

44. Eftekhari, S.; Salvatore, C.A.; Johansson, S.; Chen, T.B.; Zeng, Z.; Edvinsson, L. Localization of CGRP, CGRP receptor, PACAP and glutamate in trigeminal ganglion. Relation to the blood-brain barrier. Brain Res. 2015, 1600, 93-109. [CrossRef] [PubMed]

45. Kestell, G.R.; Anderson, R.L.; Clarke, J.N.; Haberberger, R.V.; Gibbins, I.L. Primary afferent neurons containing calcitonin gene-related peptide but not substance $P$ in forepaw skin, dorsal root ganglia, and spinal cord of mice. J. Comp. Neurol. 2015, 523, 2555-2569. [CrossRef] [PubMed]

46. Brehmer, A.; Croner, R.; Dimmler, A.; Papadopoulos, T.; Schrödl, F.; Neuhuber, W. Immunohistochemical characterization of putative primary afferent (sensory) myenteric neurons in human small intestine. Auton. Neurosci. 2004, 112, 49-59. [CrossRef] [PubMed]

47. Nuki, C.; Kawasaki, H.; Kitamura, K.; Takenaga, M.; Kangawa, K.; Eto, T.; Wada, A. Vasodilator effect of an adrenomeullin and calcitonin gene-related peptide receptors in rat mesenteric vascular beds. Biochem. Biophys. Res. Commun. 1993, 196, 245-251. [CrossRef] [PubMed]

48. Barada, K.A.; Saade, N.E.; Atweh, S.F.; Khoury, C.I.; Nassar, C.F. Calcitonin gene-related peptide regulates amino acid absorption across rat jejunum. Regul. Pept. 2000, 90, 39-45. [CrossRef]

49. Lambrecht, N.; Burchert, M.; Respondek, M.; Muller, K.M.; Peskar, B.M. Role of calcitonin gene-related peptide and nitric oxide in thegastroprotective effect of capsaicin in the rat. Gastroenterology 1993, 104, 1371-1380. [CrossRef]

50. Wynick, D.; Thompson, S.W.; McMahon, S.B. The role of galanin as a multi-functional neuropeptide in the nervous system. Curr. Opin. Pharmacol. 2001, 1, 73-77. [CrossRef]

51. Pidsudko, Z. Immunohistochemical characteristics and distribution of sensory dorsal root Ganglia neurons supplying the urinary bladder in the male pig. J. Mol. Neurosci. 2014, 52, 71-81. [CrossRef] [PubMed]

52. Sarnelli, G.; Vanden Berghe, P.; Raeymaekers, P.; Janssens, J.; Tack, J. Inhibitory effects of galanin on evoked $\left[\mathrm{Ca}^{2+}\right] \mathrm{I}$ responses in cultured myenteric neurons. Am. J. Physiol. Gastrointest. Liver Physiol. 2004, 286, 1009-1014. [CrossRef] [PubMed]

53. Piqueras, L.; Tache, Y.; Martinez, V. Galanin inhibits gastric acid secretion through a somatostatinindependent mechanism in mice. Peptides 2005, 25, 1287-1295. [CrossRef] [PubMed]

54. Fox-Threlkeld, J.E.T.; McDonald, T.J.; Cipris, S.; Woskowska, Z.; Daniel, E.E. Galanin inhibition of vasoactive intestinal polypeptide release and circular muscle motility in the isolated perfused canine ileum. Gastroenterology 1991, 101, 1471-1476. [CrossRef]

55. Botella, A.; Delvaux, M.; Frexinos, J.; Bueno, L. Comparative effects of galanin on isolated smooth muscle cells from ileum in five mammalian species. Life Sci. 1992, 50, 1253-1261. [CrossRef]

56. Vasina, V.; Barbara, G.; Talamonti, L.; Stanghellini, V.; Corinaldesi, R.; Tonini, M.; De Ponti, F.; De Georgio, R. Enteric neuroplasticy evoked by inflammation. Auton. Neurosci. 2006, 126, 264-272. [CrossRef] [PubMed]

57. Kawa, L.; Barde, S.; Arborelius, U.P.; Theodorsson, E.; Agoston, D.; Risling, M.; Hökfelt, T. Expression of galanin and its receptors are perturbed in a rodent model of mild, blast-induced traumatic brain injury. Exp. Neurol. 2016, 279, 159-167. [CrossRef] [PubMed] 
58. Lang, R.; Kofler, B. The galanin peptide family in inflammation. Neuropeptides 2011, 45, 1-8. [CrossRef] [PubMed]

59. Holzmann, B. Modulation of immune responses by the neuropeptide CGRP. Amino Acids 2013, 45, 1-7. [CrossRef] [PubMed]

60. Makowska, K.; Obremski, K.; Gonkowski, S. The Impact of T-2 Toxin on Vasoactive Intestinal Polypeptide-Like Immunoreactive (VIP-LI) Nerve Structures in the Wall of the Porcine Stomach and Duodenum. Toxins 2018, 10, 138. [CrossRef] [PubMed]

61. Korneev, K.V.; Arbatsky, N.P.; Molinaro, A.; Palmigiano, A.; Shaikhutdinova, R.Z.; Shneider, M.M.; Pier, G.B.; Kondakova, A.N.; Sviriaeva, E.N.; Sturiale, L.; et al. Structural Relationship of the Lipid A Acyl Groups to Activation of Murine Toll-Like Receptor 4 by Lipopolysaccharides from Pathogenic Strains of Burkholderia mallei, Acinetobacter baumannii, and Pseudomonas aeruginosa. Front. Immunol. 2015, 6, 595. [CrossRef] [PubMed]

62. Nguyen, M.D.; D'Aigle, T.; Gowing, G.; Julien, J.P.; Rivest, S. Exacerbation of motor neuron disease by chronic stimulation of innate immunity in a mouse model of amyotrophic lateral sclerosis. J. Neurosci. 2004, 24, 1340-1349. [CrossRef] [PubMed]

63. Choi, D.Y.; Liu, M.; Hunter, R.; Cass, W.A.; Pandya, J.D.; Sullivan, P.G.; Shin, E.J.; Kim, H.C.; Gash, D.M.; Bing, G. Striatal neuroinflammation promotes Parkinsonism in rats. PLoS ONE 2009, 4, e5482. [CrossRef] [PubMed]

64. Zhan, X.; Stamova, B.; Jin, L.W.; DeCarli, C.; Phinney, B.; Sharp, F.R. Gram-negative bacterial molecules associate with Alzheimer disease pathology. Neurology 2016, 87, 2324-2332. [CrossRef] [PubMed]

65. Liu, M.; Bing, G. Lipopolysaccharide Animal Models for Parkinson's Disease. Parkinson's Dis. 2011, 2001, 327089. [CrossRef] [PubMed]

66. Hoban, D.B.; Connaughton, E.; Connaughton, C.; Hogan, G.; Thornton, C.; Mulcahy, P.; Moloney, T.C.; Dowd, E. Further characterisation of the LPS model of Parkinson's disease: A comparison of intra-nigral and intra-striatal lipopolysaccharide administration on motor function, microgliosis and nigrostriatal neurodegeneration in the rat. Brain. Behav. Immun. 2013, 27, 91-100. [CrossRef] [PubMed]

67. Sharma, N.; Nehru, B. Characterization of the lipopolysaccharide induced model of Parkinson's disease: Role of oxidative stress and neuroinflammation. Neurochem. Int. 2015, 87, 92-105. [CrossRef] [PubMed]

68. Huang, B.; Liu, J.; Ju, C.; Yang, D.; Chen, G.; Xu, S.; Zeng, Y.; Yan, X.; Wang, W.; Liu, D.; et al. Licochalcone A Prevents the Loss of Dopaminergic Neurons by Inhibiting Microglial Activation in Lipopolysaccharide (LPS)-Induced Parkinson's Disease Models. Int. J. Mol. Sci. 2017, 18, 2043. [CrossRef] [PubMed]

69. Anitha, M.; Vijay-Kumar, M.; Sitaraman, S.V.; Gewirtz, A.T.; Srinivasan, S. Gut Microbial Products Regulate Murine Gastrointestinal Motility via Toll-like Receptor 4 Signaling. Gastroenterology 2012, 143, 1006-1016. [CrossRef] [PubMed]

70. Li, Z.X.; Li, Q.Y.; Qiao, J.; Lu, C.Z.; Xiao, B.G. Granulocyte-colony stimulating factor is involved in low-dose LPS-induced neuroprotection. Neurosci. Lett. 2009, 465, 128-132. [CrossRef] [PubMed]

71. Ye, Y.; Yang, Y.; Chen, C.; Li, Z.; Jia, Y.; Su, X.; Wang, C.; He, X. Electroacupuncture Improved Hippocampal Neurogenesis Following Traumatic Brain Injury in Mice through Inhibition of TLR4 Signaling Pathway. Stem Cells Int. 2017, 2017, 5841814. [CrossRef] [PubMed]

72. Nakasone, M.; Nakaso, K.; Horikoshi, Y.; Hanaki, T.; Kitagawa, Y.; Takahashi, T.; Inagaki, Y.; Matsura, T. Preconditioning by low dose LPS prevents subsequent LPS-induced severe liver injury via Nrf2 activation in mice. Yonago Acta Medica 2016, 59, 223-231. [PubMed]

73. Orio, M.; Kunz, A.; Kawano, T.; Anrather, J.; Zhou, P.; Iadecola, C. Lipopolysaccharide Induces Early Tolerance to Excitotoxicity via Nitric Oxide and CGMP. Stroke 2007, 38, 2812-2817. [CrossRef] [PubMed]

74. Chen, K.; Geng, S.; Yuan, R.; Diao, N.; Upchurch, Z.; Li, L. Super-Low Dose Endotoxin Pre-Conditioning Exacerbates Sepsis Mortality. EBioMedicine 2015, 2, 324-333. [CrossRef] [PubMed]

75. Mikołajczyk, A. Safe and Effective Anaesthesiological Protocols in Domestic Pig. Ann. Warsaw. Univ. Life Sci SGGW Anim. Sci. 2016, 55, 219-227.

76. Gonkowski, S.; Rychlik, A.; Nowicki, M.; Nieradka, R.; Bulc, M.; Całka, J. A population of nesfatin 1-like immunoreactive (LI) cells in the mucosal layer of the canine digestive tract. Res. Vet. Sci. 2012, 93, 1119-1121. [CrossRef] [PubMed] 
77. Gao, H.M.; Jiang, J.; Wilson, B.; Zhang, W.; Hong, J.S.; Liu, B. Microglial Activation-Mediated Delayed and Progressive Degeneration of Rat Nigral Dopaminergic Neurons: Relevance to Parkinson's Disease. J. Neurochem. 2002, 81, 1285-1297. [CrossRef] [PubMed]

78. Gao, H.M.; Liu, B.; Zhang, W.; Hong, J.S. Synergistic Dopaminergic Neurotoxicity of MPTP and Inflammogen Lipopolysaccharide: Relevance to the Etiology of Parkinson's Disease. J. Neurosci. 2003, 23, 1228-1236. [CrossRef] [PubMed]

79. Marvaldi, L.; Thongrong, S.; Kozłowska, A.; Irschick, R.; Pritz, C.O.; Bäumer, B.; Ronchi, G.; Geuna, S.; Hausott, B.; Klimaschewski, L. Enhanced axon outgrowth and improved long-distance axon regeneration in sprouty2 deficient mice. Dev. Neurobiol. 2015, 75, 217-231. [CrossRef] [PubMed]

80. Kozłowska, A.; Mikołajczyk, A.; Klimaschewski, L.; Majewski, M. Fibroblast Growth Factor (FGF) Promotes Axon Elongation in Galanin Expressing Dorsal Root Ganglia (DRG) Neurons Supplying Urinary Bladder of the Pig-an in Vitro Study. Eur. Urol. Suppl. 2016, 15, e1233. [CrossRef]

81. Loy, B.; Apostolova, G.; Dorn, R.; McGuire, V.A.; Arthur, J.S.; Dechant, G. P38 $\alpha$ and P38ß Mitogen-Activated Protein Kinases Determine Cholinergic Transdifferentiation of Sympathetic Neurons. J. Neurosci. 2011, 31, 12059-12067. [CrossRef] [PubMed]

82. Lee, S.; Levine, J. Isolation and Growth of Adult Mouse Dorsal Root Ganglia Neurons. Bio-Protocol 2015, 5, e1601. [CrossRef]

83. Heinrich, T.; Hübner, C.A.; Kurth, I. Isolation and Primary Cell Culture of Mouse Dorsal Root Ganglion Neurons. Bio-Protocol 2016, 6, e1785. [CrossRef]

84. Ohtori, S.; Takahashi, K.; Moriya, H. Existence of brain-derived neurotrophic factor and vanilloid receptor subtype 1 immunoreactive sensory DRG neurons innervating L5/6 intervertebral discs in rats. J. Orthop. Sci. 2003, 8, 84-87. [CrossRef] [PubMed]

85. Christianson, J.A.; Liang, R.; Ustinova, E.E.; Davis, B.M.; Fraser, M.O.; Pezzonea, M.A. Convergence of Bladder and Colon Sensory Innervation Occurs at the Primary Afferent Level. Pain 2007, 128, 235-243. [CrossRef] [PubMed]

(C) 2018 by the authors. Licensee MDPI, Basel, Switzerland. This article is an open access article distributed under the terms and conditions of the Creative Commons Attribution (CC BY) license (http://creativecommons.org/licenses/by/4.0/). 